\title{
Development of Personalized Learning Environment (PLE) for Malaysian School Environment Based on ADDIE Model
}

\author{
Che Ku Nuraini Che Ku Mohd, Faaizah Shahbodin \\ Faculty of Information and Communication Technology \\ Technical University of Malaysia, Melaka \\ Faculty of Information and Communication Technology \\ Technical University of Malaysia, Melaka
}

\begin{abstract}
Personalized Learning Environment (PLE) is a new concept in designing and developing an online learning. PLE is more focused on individual learning rather than the instructor, facilities, resources and tools. PLE has also played an active role in improving the effectiveness of learning. This paper aims to share the development and preliminary findings on PLE in teaching Form 2 Science. The samples involved are Form 2 students at secondary schools. The study group was composed of 90 students. The topic chosen is Nutrition. In this study, the development process of the environment was examined according to the Analyze, Design, Develop, Implement, Evaluate, Instructional Design Model (ADDIE). There are divided into three phases. Phase one is Analysis which includes literature survey and collection of preliminary analysis data. Second phase is Designing and Development which adopt ADDIE model as a basis for multimedia development. The last phase is Testing and Evaluation.
\end{abstract}

\section{Indexing terms/Keywords}

ADDIE; Multimedia; Methodology; PLE; Science.

\section{Academic Discipline And Sub-Disciplines}

Education

\section{SUBJECT CLASSIFICATION}

Science Subject

\section{TYPE (METHOD/APPROACH)}

Survey

\section{Council for Innovative Research}

Peer Review Research Publishing System

\section{Journal: INTERNATION JOURNAL OF COMPUTERS AND TECHNOLOGY}

Vol. 13, No. 7

editorijctonline@gmail.com

www.ijctonline.com, www.cirworld.com 


\section{INTRODUCTION}

Online learning in higher education continues to grow yet there are concerns about attrition and lack of student success in online environments (Pemberton \& Moallem, 2013). Education has only scratched the surface on personalizing the learner experience (Wolf, 2010). The number of college students in online courses increased from 1.6 million students taking at least one online course in 2002 to over 6.1 million students taking at least one online course in and "there is no compelling evidence that the continued robust growth in online enrollment is at its end" (Allen \& Seaman, 2011). The potential of technology to lower the threshold of engagement in informal learning renders the need for physical resources example classrooms less demanding, prompting the desire for open and distributed learning environments (Siemens, 2010).

Increasing online learning in higher education is moving toward open sourcing. Translating the benefits of technology into innovative practices of MOOCs offers a huge number of learners worldwide the chance to use tools such as wikis, blogs, Twitter, and Facebook to create and share content and to develop learning networks (Mohsen \& Kristiina , 2014). These initiatives offer obvious advantages: eliminating geographic and economic barriers to education, allowing students access to multiple learning opportunities, promoting lifelong learning, and augmenting face-to-face and traditional education in new ways (Clobridge, 2012).

The idea of "personalizing" education is not new but it certainly has not been widely researched or accepted, especially in higher education (Keefe \& Jenkins, 2008). A review of the history of education shows that instruction and learning were once highly personal and provided in one-on-one settings where the learner interacted with an expert through oral histories, apprenticeships, one-one-one tutoring, or mentoring (Andersen, 2011). Personalized learning cannot take place at scale without technology (Wolf, 2010). By integrating the principles of personalized learning with the tools of technology, some educators argue that they can create the kind of customized learning environment that has the potential for breaking schools out of the industrial-age model of education and bring about true 21st century school reform (Demski, 2012). Personalized learning really takes into consideration that long tail of interest, of prior motivation, of languages. By integrating the principles of personalized learning with the tools of technology, some educators argue that they can create the kind of customized learning environment that has the potential for breaking schools out of the industrial-age model of education and bring about true 21st century school reform (Demski, 2012).

\section{METHODOLOGY}

ADDIE is five-phase systematic model used to create sound instructional products for a variety setting. Its name is an acronym of the capital letters of the words: Analyze Design, Develop, Implement, and Evaluate which comprise the five steps as follows (McGriff, 2000; Kaminski, 2007). Each phase represents a series of tasks that help to ensure development efforts stay on tract, on time, and on target. Completing each phase satisfactorily increase the chance that the information presented ultimately remains relevant to the needs of the audience. Each phase of the ADDIE model is an important element of the instructional design process. In each phase, the instructional designer makes decisions that are critical for ensuring the effectiveness of the instructional experience. Figure 2 shows the ADDIE model adopted from http://nschutte.com/projects/instructional-design-process-using-addie-model/.

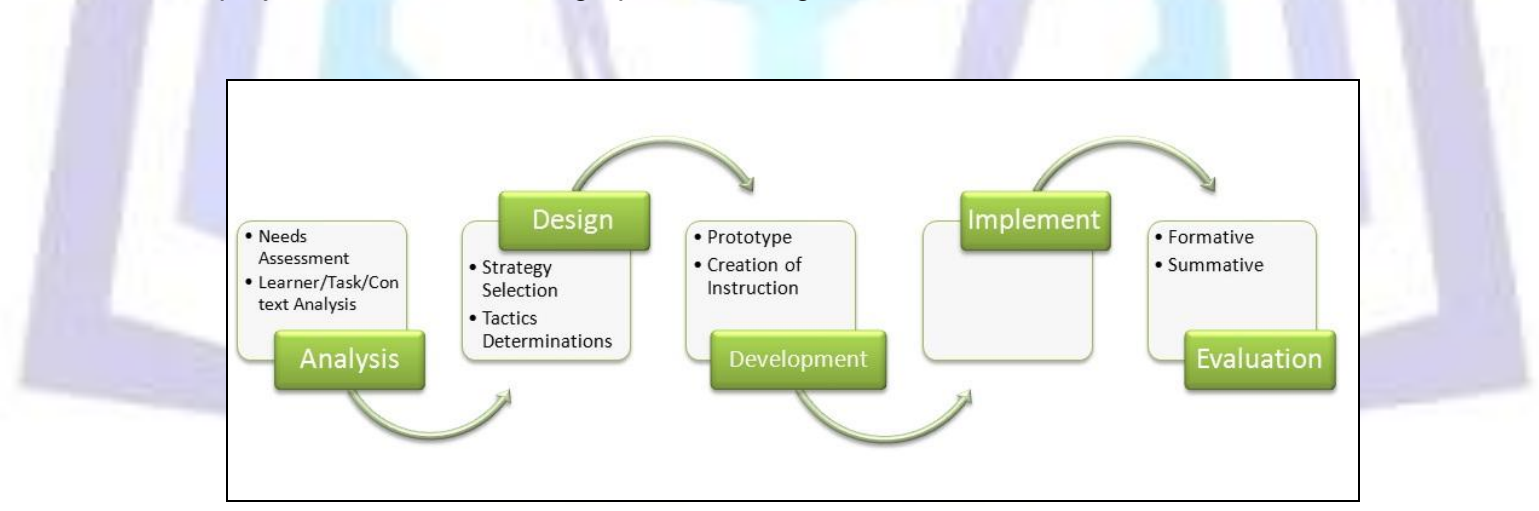

Figure 1: ADDIE Model

\section{A. Analysis phase}

In analysis phase, the student's problems in learning Science subject are defined. Besides that, the problems that directly influence the motives of the research must be identifying. After that, goals and objectives are established and the PLE environment and methodology were identified so that student's requirements for assessment will achieve through this model. This phase defined the requirement of project, independent of how this project is accomplished. We have defined the problem that occur and the deliverable product of the end project. Focused group interviews, literature survey and survey will be conducted to verify requirement. The application should be determined too on what it will looks like, what its content will be, how it will perform, and for whom it is intended.

\section{B. Design phase}

Design a prototype based on the model proposed and concerned with the learning approach. Based on expected outcomes, produced from the above analysis, the interactive prototype can be designed by selecting content, media and type of interactivity that best underpins the objectives. The user-centered design is used to approach prototype design. It 
is include layout and design, color scheme, navigation, graphics and other elements of the look and feel. These are steps used for the design phase:

- Storyboards.

- Design the user interface and user experience.

- Navigation design.

-PLE concept design.

-Prototype creation (input and output design).

\section{Development phase}

The develop stage integrates PLE modules. At this point developing process initiates based on the storyboard created and concluded in an Alpha version of the product. The development of this application is carried out in this phase. By using the storyboard as guide, the development will start with interface development followed by the content. Each module will be built and ensure each button and function is working properly.

\section{Implementation phase}

This phase is to make sure the prototype is functional. Develop a multimedia application based on the layout and storyboard. The entire multimedia element, problem scenarios set, and web will be developed. All the modules and elements will be integrated to produce a final product that is ready to use. Prior to full-scale implementation, it is usually helpful to demo the application with a small group so that their feedback can be used to revise and improve the software.

\section{E. Evaluation phase}

This phase is the activities that require improvement for increasing the research result. Final documentation will be prepared and project will be launch. Evaluation process is collecting feedbacks from end users. Any dissatisfaction from end users should be taken into action before finalizing the product. The questionnaire from the testers will be used for collecting feedback from the users of the software regarding the interface, PLE methodology, and its content.

\section{PRELIMINARY ANALYSIS}

Questionnaires are distributed to find the most difficult topic in Science Form 2 subject. Table 1 shows the findings of preliminary analysis to find the difficult topic in Science Form 2 subject. Researcher conducts an interview with Science Form 2 teachers to find the most difficult topic. Nutrition is most difficult and also having many subtopics. The subtopics of Nutrition are Classes of Food, The Importance of a Balance Diet, Human Digestive System, Absorption of Digested Food, Reabsorption of Water and Defecation and Healthy Eating Habits.

Table 1. Preliminary Analysis Findings to Find Difficult Topic in Science Form 2

\begin{tabular}{lllllll}
\hline & $\mathbf{N}$ & Min & Max & Mean & Std. Deviation & Variance \\
\hline Topic1 & 90 & 1 & 5 & 2.00 & .835 & .697 \\
Topic2 & 90 & 1 & 5 & 3.99 & 1.117 & 1.247 \\
Topic3 & 90 & 1 & 4 & 2.94 & .904 & .817 \\
Topic4 & 90 & 1 & 5 & 2.84 & .911 & .829 \\
Topic5 & 90 & 1 & 5 & 2.54 & .901 & .813 \\
Topic6 & 90 & 1 & 5 & 2.72 & 1.006 & 1.012 \\
Topic7 & 90 & 1 & 5 & 3.11 & 1.054 & 1.111 \\
Topic8 & 90 & 1 & 5 & 3.02 & .861 & .741 \\
Topic9 & 90 & 1 & 5 & 2.67 & .960 & .921 \\
Topic10 & 90 & 1 & 5 & 2.09 & 1.098 & 1.205 \\
\hline $\mathrm{N}$ & 90 & & & & &
\end{tabular}

A set of questionnaire is distributed to 90 students in Form 2 students at SMK Malim, Melaka, Malaysia. The data from the questionnaire are analyzed by using Statistical Package for the Social Science (SPSS) version 17.0. Few students have interviewed for the feedback regarding to the Nutrition topic. According to the feedback received, they have to remember the facts that had been taught in this topic. They also were boring with this topic. This boredom became more serious as students have not exposed on how improve the learning processes in this topic. Table 2 shows the frequencies for Topic 2 
which is Nutrition in Science subject. $40 \%$ agree and $38.9 \%$ strongly agree that Nutrition is the hardest topic compared to other topics. Only $3.3 \%$ states that Nutrition is the easiest topic followed by easy which is $12.2 \%$.

Table 2. Frequencies for Topic 2 Nutrition

\begin{tabular}{lllll}
\hline Valid & Frequency & Percent & Valid Percent & Cumulative Percent \\
\hline Easiest & 3 & 3.3 & 3.3 & 3.3 \\
Easy & 11 & 12.2 & 12.2 & 15.6 \\
Middle & 5 & 5.6 & 5.6 & 21.1 \\
Hard & 36 & 40.0 & 40.0 & 61.1 \\
Hardest & 35 & 38.9 & 38.9 & 100.0 \\
\hline Total & 90 & 100.0 & 100.0 & \\
\hline
\end{tabular}

Table 3 shows the analysis of the students need internet for their study. Based on the statistic, it shows that $40 \%$ strongly agree and $38.9 \%$ agree that students need internet for their study. Only $2.2 \%$ not agree and $1.1 \%$ strongly not agrees of using internet in their study. Majority of students associates learning with acquiring information by assessing internet. They also extremely value, useful tools which help them to plan their tasks, save time, simplify complicated tasks and definitively, have fun.

Table 3. Students Need Internet for Their Study

\begin{tabular}{lllll}
\hline & Frequency & Percent & Valid Percent & Cumulative Percent \\
\hline Strongly Agree & 36 & 40.0 & 40.0 & 40.0 \\
Agree & 35 & 38.9 & 38.9 & 78.9 \\
Middle & 16 & 17.8 & 17.8 & 96.7 \\
Not Agree & 2 & 2.2 & 2.2 & 98.9 \\
Strongly Not Agree & 1 & 1.1 & 1.1 & 100.0 \\
\hline Total & 90 & 100.0 & 100.0 & \\
\hline
\end{tabular}

Therefore, this research is carried out to develop a PLE prototype that can be used by students for teaching Form 2 Science students. The system will be based on student's learning styles preferences. This research will provide a model to identify and assess student's preferences dominant learning styles which are Visual, Auditory and Kinesthetic and it will be used to develop the system. The most crucial part of this research would be the development of module for each types of learning styles. The behavior and performance of the students will be measured. A framework and model will be develop and generated focusing on the cognitive skills towards PLE. The importance of this research is to manage the integration of multiple intelligence Personalized Learning Environment (PLE) for teaching Science Subject. It will provide students engagements in learning process, increased the responsibility and accountability of students. Students are become a creator instead of become a consumers of information. At the same time, PLE will provide students real life connection, forum for sharing of ideas, promotes creativity among students, critical thinking, deep learning and understanding.

\section{EXPECTED RESULTS}

This research will provide a new model Science subject for Form 2 students based on learning styles preferences using PLE approach.

\section{CONCLUSIONS}

Preliminary analysis findings from this study seem to suggest that, perhaps not surprisingly, computers are being used in schools in similar ways to the other implementations of technology in the classroom. If we consider the possibilities for the use of PLE that are discussed in the introduction, we need to work more on making sure that teachers receive effective training to understand what the potentials are of such technologies and the powers that be need to make sure that access to the internet makes this kind of activity possible.

\section{ACKNOWLEDGMENT}

Special thank goes to my helpful supervisor, Assoc. Prof. Faaizah Shahbodin. Great deals appreciated go to the contribution of my faculty - Faculty of Information and Communication Technology, Universiti Teknikal Malaysia Melaka (UTeM). Last but not least I would like to thank my friends especially those who work together for the wise idea throughout this study. 


\section{REFERENCES}

[1] Allen, I. E., \& Seaman, J. (2011). Going the Distance: Online Education in the United States.

[2] Andersen, M. H. (2011).The world is my school: Welcome to the era of personalized learning. Futurist, 45(1), $12-17$.

[3] Bekele, T. A., (2010). Motivation and satisfaction in internet-supported learning environments: A review. Educational Technology \& Society, 13(2), 116-127.

[4] Chan Lin, L. (2009). Applying motivational analysis in a web-based course. Innovations in Education \& Teaching International, 46(1), 91-103.

[5] Clobridge, A. (2012, August 30). MOOCs and the changing face of higher education. Information Today.

Retrieved from http://newsbreaks.infotoday.com/NewsBreaks/MOOCs-and-the-Changing-Face-of-Higher-Education84681.asp.

[6] Demski, J. (2012). This Time It's Personal. T H E Journal, 39, 32-36.

[7] Hart, C. (2012). Factors Associated With Student Persistence in an Online Program of Study: A Review of the Literature. Journal of Interactive Online Learning, 11(1), 1541-4914

[8] Hussar, W. J., \& Bailey, T. M. (2011). Projections of Education Statistics to 2020. (NCES 2011-026). Washington, DC: U.S. Government Printing Office.

[9] McGriff, S. J. (2000). Instructional system design (ISD): Using the ADDIE model. Retrieved June 23, 2006 from http://www.personal.psu.edu/faculty/s/j/sjm256/portfolio/kbase/IDD/ADDIE.pdf

[10] Keefe, J. W., \& Jenkins, J. M. (2008). Personalized Instruction: The Key to Student Achievement (2nd Ed.). Lanham, MD: Rowman \& Littlefield Education.

[11] McGriff, S. J. (2000). Instructional system design (ISD): Using the ADDIE model. Retrieved June 23, 2006 from http://www.personal.psu.edu/faculty/s/j/sjm256/portfolio/kbase/IDD/ADDIE.pdf

[12] Mohsen Saadatmand \& Kristiina Kumpulainen (2014). Participants' Perceptions of Learning and Networking in Connectivist MOOCs. MERLOT Journal of Online Learning and Teaching. Vol. 10, No. 1, March 2014.

[13] Pemberton, A. \& Moallem, M. (2013). The Impact of Personalized Learning on Motivation in Online Learning. In R. McBride \& M. Searson (Eds.), Proceedings of Society for Information Technology \& Teacher Education International Conference 2013 (pp. 907-914). Chesapeake, VA: AACE. Retrieved from http://www.editlib.org/p/48228.

[14] Siemens, G. (2010, February 16). Teaching in social and technological networks [Web log post]. Retrieved from http://www.connectivism.ca/?p=220

[15] Wolf, M. A. (2010). Innovate to educate: System [re]Design for personalized learning; A report from the 2010 symposium. Washington, D.C.: Software \& Information Industry Association.

\section{Author' biography with Photo}

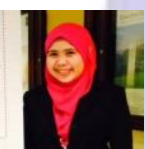

Che Ku Nuraini Che Ku Mohd received her Degree in Computer Science (Interactive Media) in 2008 and a Master of Science in Information and Communication Technology (Multimedia) in 2011. She is currently working on her PhD in ICT at Universiti Teknikal Malaysia Melaka (UTeM), Melaka, Malaysia. Her interests are primarily on Multimedia Applications, Human Computer Interaction and Personalized Learning Environment (PLE).

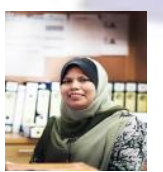

Faaizah Shahbodin is an Associate Professor at Faculty of Information and Communication Technology, Universiti Teknikal Malaysia Melaka (UTeM). She received her Degree in Computer Science in 1994 from Universiti Utara Malaysia (UUM), and Master in Computer Science in 1997 from Queensland University of Technology (QUT), Brisbane, Australia. She completed her Ph.D in Multimedia Education Systems at University Kebangsaan Malaysia (UKM). Her research interests are primarily on Problem Based Learning, multimedia applications, Creative Contents and User Interface Design. 